\title{
Mechanism of shale gas occurrence
}

\author{
LEI CHEN $^{12}$, ZHENXUE JIANG ${ }^{3}$ \\ 1 Key Laboratory of Deep Oil and Gas, China University of Petroleum (East China), Qingdao 266580, China \\ 2 School of Geosciences, China University of Petroleum (East China), Qingdao 266580, China \\ 3 Unconventional Natural Gas Institute, China University of Petroleum, Beijing 102249, China
}

The exploration practices of marine and lacustrine shale gas in the Upper Yangtze Platform, South China show that there is a huge difference in gas content, which is mainly related to the difference of pore structure. This study is focused on marine Longmaxi and lacustrine Da'anzhai shales in the Upper Yangtze Platform, and their pore structure characteristics were compared and the mechanism of shale gas occurrence were discussed. First, the pore structures of marine and lacustrine shales were characterized and the effects of organic matter abundance, maturity and inorganic minerals on porosity were investigated. Then the contributions of different components to porosity were evaluated and the occurrence mode of methane in the pores of marine and lacustrine shales was established. The results show that (1) Three pore types can be observed in both marine and lacustrine shales: organic matter-hosted pores (OM pores), framework minerals-associated pores (FM pores), and clay minerals-associated pores (CM pores). OM pores are more developed in marine shale and $\mathrm{CM}$ pores are more developed in lacustrine shale. (2) Low pressure gas adsorption (LPGA) results show that the micropores of marine shale are dominated by pores of 0.4-0.7 $\mathrm{nm}$ and the micropores of lacustrine shale are dominated by pores of $0.5-0.9 \mathrm{~nm}$, while the mesopores of marine shale are dominated by pores of 2-10 nm and the mesopores of lacustrine shale are dominated by pores of 3-30 nm, which are consistent with MIP results. (3) Organic matter has an impact on porosity of marine and continental shales but is not the most important controlling factor. And the contribution of organic matter to porosity in marine shale is greater than the contribution of organic matter to porosity in lacustrine shale. Shale porosity increases first and then decreases with the increase of maturity, which may be related to the carbonization of organic matter. (4) OM pores and CM pores tend to be preserved due to the presence of rigid grains that form rigid frameworks preventing these pores from collapsing. FM pores are mainly related to the dissolution of framework minerals by organic acids, and these dissolution pores can greatly improve the porosity and permeability of shale. (5) Quantification of porosity as related to mineralogy shows that OM pores contribute approximately $37 \%$ to total porosity of marine shale and $24 \%$ to total porosity of lacustrine shale and CM pores contribute approximately $53 \%$ to total porosity of marine shale and $67 \%$ to total porosity of lacustrine shale. (6) Shale gas occurrence is mainly controlled by the distribution mode of pore systems which are composed of OM pores, FM pores and $\mathrm{CM}$ pores. It is due to higher percentage on $\mathrm{OM}$ pores and lower percentage on $\mathrm{CM}$ pores that gas content of marine shale is generally higher than that of lacustrine shale. 